\title{
The Implementation of Integrated Curriculum in the Primary School: A Case Study of Sekolah Alam Cikeas
}

\author{
Maisyafriana \\ Magister Program of English Language Education, State \\ University of Jakarta, Indonesia
}

\author{
Adelina Siahaan \\ Magister Program of English Language Education, State \\ University of Jakarta, Indonesia
}

\author{
Evi Mala Wijayanti \\ Magister Program of English Language Education, \\ State University of Jakarta, Indonesia
}

\begin{abstract}
Curriculum for the primary grades that is established by the Indonesian government includes reading, writing, listening, speaking, social studies, math, science, physical education, music, and visual arts. Sekolah Alam Cikeas implements integrated curriculum that allows children to pursue learning in a holistic way, without the restrictions often imposed by subject boundaries. An integrated curriculum aims to build a student-centered curriculum that invite students to take parts, and to have metacognitive. This curriculum emphasizes the higher order thinking skills, cooperative learning on social issues and tolerance of others' values and concerns. The previous study conducted by Saez and Sancho in 2017 in a higher education. It found out that integrated curriculum provides a worthwhile training opportunity to achieve learning of greater significance and depth. This paper seeks to elaborate the implementation of integrated curriculum at Sekolah Alam Cikeas Primary School. A case study is carried out for a period of one semester.

The result shows that there are three ways in implementing the integrated curriculum in Sekolah Alam Cikeas. First, thematic including the process of arranging the whole theme will be implemented during a year. Second, students' project based. There are seven projects implemented in the school, they are cooking, business, green lab, assembly, outing, students' book, and careshare-respect project. Third is the student's activity unit including saving rubbish, radio, ecoshop and agribusiness. Those activities facilitate students learn best when they are fully immersed in an educational experience and consider multiple views and connections across subjects.
\end{abstract}

Keywords: integrated curriculum, thematic, projectbased, students' activity, primary school

\section{INTRODUCTION}

Education is the process of facilitating learning or acquisition of knowledge, skills, values, belief and habits. Sekolah Alam Cikeas implements integrated curriculum that allows children to pursue learning in a holistic way, without the restrictions often imposed by subject boundaries. According to Vars (2001), an integrated curriculum aims to build a studentcentered curriculum that invite students to take parts, and to have metacognitive. This curriculum emphasizes the higher order thinking skills, cooperative learning on social issues and tolerance of others' values and concerns.

Watkins and Kritsonis (2001) claims that the meaning and the significance of the materials in an integrated curriculum can be noticed by the students. The students obtain deeper comprehension of the material. (Watkins \& Kritsonis, 2011). An integrated curriculum provides children for lifelong education. Students are able to relate the experience that they obtained in their learning project to their experience in their real life (Mustofa, 2011).

The question that will be addressed by this study is as follows: "How is integrated curriculum implemented in Sekolah Alam Cikeas Primary School?"

The general objective of the study was "to elaborate the implementation of integrated curriculum at the Sekolah Alam Cikeas Primary School." The study only covers the integrated curriculum that is implemented in the primary school of Sekolah Alam Cikeas, Gunungputri, Kabupaten Bogor, West Java.

Many experts in education have their own definition of integrated curriculum. Campbell and Henning (2010) believed that an integrated curriculum is learning organized around problems and issues of the students. Shriner, Schlee, and Libler (2010) believed that an integrated curriculum applies skills and vocabulary from more than one subject area to examine a 
as cross-case themes. The instruments that were used are guidance note, a standard reporting structure for writing up the case study.

\section{FINDINGS AND DISCUSSION} collaboratively identified by educators and young people, without regard for subject-area lines (p. 55). Malik \& Malik (2011) defined integration as the organization of teaching matter to bring subjects together that are usually taught separately.

Integrating the curriculum is an incredibly important issue in the field of education. As mentioned by Campbell and Henning (2010), knowledge today is becoming more interdisciplinary and integrated, which calls for more interdisciplinary and integrated learning in public schools. Teachers are continually looking for ways to engage their students and deepen their understanding of the content.

According to Bolak, Bialach, and Dunphy (2005), when students get the opportunity to discover new knowledge and apply that knowledge, they are more likely to succeed. Gains in achievement are noticeable, especially when students are engaging in hands-on activities.

Students are capable of making meaningful connections between different disciplines. Integrating the curriculum allows students many opportunities to understand why they need to know certain skills or pieces of knowledge. Students can master the content and understand it at a higher level (Watkins \& Krisonis, 2011). It is important in education for students to be pushed to higher levels of thinking with important content. Critical thinking is highly emphasized in an integrated curriculum because it motivates students and teachers simultaneously.

Harrell (2010) reports that integrating curriculum enhances student learning. Several writers also report that students in schools that focus on and take part in integrated curriculum perform better on standardized tests and state exams than students in schools that do not (Shriner et al., 2010; Campbell \& Henning, 2010; Hinde, Osborn, \& Dorn, 2007).

\section{METHOD}

The method used in this research is qualitative method. The approach of the study is an intrinsic case study in which the focus is on the case itself. The research is going to do in the primary school Cikeas Natural School (Sekolah Alam Cikeas).

The source of the data uses multiple sources, such as teachers, the principals and documents such as the curriculum book, spider web, long term plan, semester plan, weekly plan, daily plan, work sheets are also included as source of data.

The data collection forms are using multiple sources, such as deep interviews with the teachers and the principal. The researcher also did the intensive observations, and collect documents that support the research. The data are analyzed through description of the case and themes of the case as well

\section{Findings}

\section{Thematic}

\subsection{Planning the Whole Year Themes}

Teachers in each level will become the team who are the facilitators for students to learn. They select themes which must be determined before the academic year starts, so the teachers need several days to do the Preparation Meeting. The teachers explore the resources and decide which books will be the main resources. They also have to make the time tables to coordinate teaching and learning schedule.

Even though Sekolah Alam Cikeas Primary School has its own curriculum, but it still uses the 2013 National Curriculum as a guidance. There are several themes in a semester. For instance, in grade 3 , there are 8 themes in a year. So, there are four themes for the first semester, the first theme is The growth and the development of the living things, the second theme is Loving plants and animals, the third theme is Things around me and the fourth theme is My obligations and my right. Through these themes, they students must learn the basic skills, such as reading, writing and mathematics, and also social skills and problem solving.

\subsection{Making Spider Web}

After selecting the themes, the teachers must make a spider web or mind map for each theme. The theme become the center of the spider web. There some lines from the center, they are lines for Mathematics, Science, Social, Bahasa Indonesia, English, Art and ICT. From mathematics there are lines to some materials that will be studied by student during the theme. From Science, there are lines to some materials that will be studied by student during the theme. It's the same things to Social, Bahasa Indonesia, English, Art and ICT. The materials must relate to the theme.

\subsection{Making Lesson Plan}

The next step, the teacher makes a semester plan. A semester consists of 18 effective weeks. The teacher put the syllabus into nine column of subjects and 18 rows of weeks. The next step, the teachers make weekly plan for every subject. The last step, the teacher must make Daily Plan. Daily plan is a very detailed of student's activity. In the daily plan, there must be the learning aims (learning goals) and the outcomes (learning objectives). The teacher also determine the method she will use as well as the material and learning activities. In the daily plan there must also the choices how the teacher will assess the student, is it with observation, writing test, interview and student self-assessment. The teacher also writes the resources and equipment she will need for teaching aids. 


\section{Project}

The cooking project is one of way to integrate the curriculum. Before the project starts, the teacher makes the proposal of the project. The teacher determines the learning goals and learning objectives of the project. Then the teacher determines how the students learn the subjects, such as Science, Social, Math, Language, English, and Art. She makes the worksheet for students to learn those subjects.

The other project is business project. The business project also must integrate with all subject, such as Mathematics, Science, Social, Math, Language, English and Art. In the business project, the students can create a market day event, a café, a food bazaar, a Cooperation, a performance event which students sell the ticket to other students. Like the cooking project, the teacher also determines how the students learn Science, Social, Math, Language, English, and Art. She also makes the worksheet for students to learn those subjects.

In the Green Lab project, students can do the planting project, or observe the plants in the school, or raising fish. They make journals or report about their project. Assembly project is learning activity which is related to performance art. Once in a semester the students perform in front of all the students. The teacher and students decide together what they will perform. The performance can be singing, dancing or a drama/play. They practice and prepare for the costume and stage attributes together.

The students need to learn outside of the school area. They need to visit places that are related to what they are learning. Once in a semester the students must go outing for leaning, it's called outing project. The teacher must find a place that can enrich the students' knowledge and understanding. The places can be museums, botanical garden, zoo, government offices, historical places, etc. The teacher determines the learning goals and learning objectives of the project. Before visiting the place, the students plan what they will study in there, and after visiting the place, the make a report about what they have learned from the visit.

Students need to have an experience to write a book in students' book project. They work together to compile their works to be a book. Care, Share and Respect is a program that students do to help unfortunate people. This program will soften their heart. It will emerge their empathy. The students can visit an orphanage, nursing home, visit poor friend's house, or helping poor people around the school, teaching students form other schools how to separate rubbish.

\section{Student's Activity Unit}

Saving rubbish unit or Reduce Reuse and Recycle (3R) is a student's activity unit which encourage students to separate rubbish at home. Every student must get used to separate rubbish at home. They bring recyclable rubbish to school. They weigh the rubbish, make a note on the saving books they have, converse it to Rupiah and totalize it. At the end of the year, the students get the money form the recycling rubbish that they bring to school. With this activity the student has learned mathematics by weighing, multiplying and adding, they also have done action to look after the environment.

Unit Radio is where students do broad casting in groups or individual. In broadcasting activity, they report what they study in the classroom. They can report about their science and social lessons, history or their activities in the classroom. This activity is integrated to Bahasa Indonesia or English by rehearsing poems or tell a story.

In the Ecoshop activity, students collect decent used clothes from other students. Grade three students who usually work in this unit. They sort the clothes, label them with the appropriate price, it's usually very cheap, such as Rp 1.000, Rp 2.000, until Rp 5.000. They also promote the shop by making fliers and spread them to the people around the school. They open the shop once in a week, usually on Friday at 13.00-14.00. They work in the shop in groups of 5 or 6 . Besides looking after the environment by doing the reuse, the have learned mathematics by doing the addition and subtraction during serving the customers. They also learn language and art when they make the fliers, and the most important thing is they have done the charity and learned how to run a business.

Students sell the products of the plants of the green lab project. They can sell vegetables or processed product from agriculture. They sell the product in an event called Thursday Market. Students learned how to pack their product, determine the price, decorate their booth and learn mathematics by adding and subtracting during the selling and buying process. This activity is interactive and meaningful for the students. When students have the opportunity to make connections between their personal life experiences and the content in the classroom, their knowledge will expand and be much more meaningful to them. Integrating the curriculum actively engages students in lessons and extends their thinking skills. Integrated curriculum also allows students to make connections among different subject areas and to their own lives. When students make these connections and understand why they need to know certain skills or pieces of knowledge, the learning process becomes positive for the students(Costley, 2015)

\section{Discussion}

This approach requires teachers to move from a role and an identity of expert to another of guide and facilitator of student learning.(Alonso Sáez \& Berasategi Sancho, 2017). The teachers in this school are called facilitator, they facilitate the students to learn. There are two facilitators in a class, who are with the students from the beginning of the class until the students go home.

It suggests that students learn best when they are fully immersed in an educational experience and consider multiple views and connections across subjects.(Park, 2008) Miss Ine Agustiyani, the principal and former primary teacher explained that the students learned best because they were encourage to 
involve directly in the learning activity. They can relate one material to the other, so they can understand well. For example, when the prime material is science about spring force, it can be integrated with Art, Indonesian language, and Mathematics. In Art activity, the students decorate catapult wood with paint. In Indonesian language activity they write a story about their experience playing catapult with friends. Because the experience of observation, creating, writing, the students have better understanding about the materials. Mr. Azwar, the facilitator of grade 5 explained that with integrated curriculum the students get the knowledge and skill holistically about a material. From a material, the students learn many things. For example, from a stone, students learn about weight (math), the form of stones (science), economy activity which related to stones such as stone miner, stone carrier transportation, the user of stones for building or craft (social), stone carving (art), verse in Qur'an which use the word stone as an analogy of the hard of human's heart in denying God, stone for istinja (Religion).

Before giving an assignment, facilitator usually the students open questions that encourage them to give the right reasons. Engagement, motivation, student-centered approaches, and gains in critical thinking skills are all worthy and valid reasons to use an integrated curriculum approach in the classroom(Costley, 2015).

There are many activities which have connection with the students' personal life experience. Care, share and respect activity will open their eyes that they can help many people around them that are unfortunate. They can do something that is useful for other people. The activity in saving rubbish unit are connected with the students' real life. They produce the rubbish, they separate between an-organic rubbish and organic rubbish at home, and bring the an-organic rubbish to school to be recycled. They learn addition and multiplication from this activity. In unit Radio they can tell their story based on their experience. Activity in unit Ecoshop is very meaningful for the students. They bring their unwanted but good condition clothes to school, sort them, price them, and sell them with a low price to the poor. They sell vegetables and fruit that they usually eat to people or parents. They count the money, put aside the capital and get the profit. When students have the opportunity to make connections between their personal life experiences and the content in the classroom, their knowledge will expand and be much more meaningful to them. Integrating the curriculum actively engages students in lessons and extends their thinking skills. Integrated curriculum also allows students to make connections among different subject areas and to their own lives. When students make these connections and understand why they need to know certain skills or pieces of knowledge, the learning process becomes positive for the students(Costley, 2015). Nara and Putri, students from grade for said that they love school, because they can do exploration in the school. Asha from grade 5 said that she was excited to go to school and to meet her friends. Abhisam from grade 5 said that studying in the school is fun.

An integrated curriculum also has many benefits. Because of integrated teaching, students develop a love of learning, increase self-confidence, attain a commitment to the democratic group process, and increase their critical thinking skills and concern for other people. (Vars, 2001). In Care, share and respect activity, the students see that some people are not so lucky, they know more about something than other people, that condition make the students concern for other people. Every week they throw the election of the new class chairman. Every student has an opportunity to be a leader. The chairman also leads the election for the next week chairman. He leads his friend when they make a line when leaving their classroom to go to other place in the school, such as to the library, music room, greenlab, etc. Every day the students who are on duty take turn to lead the opening class prayer, before lunch prayer and closing class prayer. Every morning the students sit in a circle on the floor. After the prayer, they have morning talk. In this activity, they have the opportunity to express their opinion or telling their story. Those activities will increase the students' self-confidence.

When students do their projects, they usually work in a group. They learn to cooperate. Cooperation aims to give the students opportunities to involve in discussion, responsible in their learning, so they will be critical thinkers. Critical thinking plays an important role in cooperation to find the right reason and work on constructive task. One of the ways to improve the ability of critical thinking is through developing the observation ability. Through observation the students will find the problem solution, such as by identifying the strength and weakness, pro and con of a problem, incidents or things that are observed. Those activities will encourage students to develop their critical ability.

The school environment that is spacious, green, consists of many kinds of plants which will invites many kinds of insects will bring up the students' love of learning. When the students get out of class room and explore the school environment, they will be getting new experiment from the school environment, by observing plants, soil, insects, etc.

The students take on personal challenges and find the way how to overcome when they do the outbound activity. Every week they are given new challenge to conquer, such as bamboo bridge, two lines bridge, climbing wall, etc.

The activities in student activity unit such unit Radio, Ecoshop, unit Reduce, reuse, recycle (3R), and students have opportunity to turn something passive into something active. The can change the unwanted rubbish into money that they keep in their saving book. They also can turn old clothes to be useful for other people and the get some money from selling the clothes. In the unit radio they can inform audiences with news which they collect by themselves. The students can cultivate an interest in the arts in the assembly project. They cooperate with their friends in the classroom to create and perform a play or vocal group. They can dance and sing together. Reflexion is important part of learning. When the students are closed to nature they have opportunities to slow down, practice mindfulness, and reflect on the word around them. 
[5] Costley, K. C. (2015). Research Supporting Integrated Curriculum: Evidence for Using this Method of Instruction in Public School Classroom. Journal of Curriculum Studies, 23(6), 107-117.

With integrated curriculum the students learn best because they were encouraged to involve directly in the learning activity. Because the experience of observation, creating, writing, the students have better understanding about the materials. When students have the opportunity to make connections between their personal life experiences and the content in the classroom, their knowledge will expand and be much more meaningful to them.

An integrated curriculum also has many benefits. Because of integrated teaching, students develop a love of learning, increase self-confidence, attain a commitment to the democratic group process, and increase their critical thinking skills and concern for other people.

\section{REFERENCES}

[1] Beane, J. (1997). Curriculum integration: Designing the core of democratic education. New York, NY: Teachers College Press.

[2] Bolak, K., Bialach, D., \& Dunphy, M. (2005). Standards-based, thematic units integrate the arts and energize students and teachers. Middle School Journal, 36(5), 9-19.

[3] Bredekamp, S. \& Rosegrant, T. (Eds). (1992). Reaching potentials: Appropriate curriculum and assessment for young children. Volume 1. Washington, DC: National Association for the Education of Young Children.

[4] Campbell, C., \& Henning, M. (2010). Planning, teaching, and assessing elementary education interdisciplinary curriculum. International Journal of Teaching and Learning in Higher Education, 22(2), 179-186.

[6] Gehrke, N. J. (1991). Exploration of teachers' development of integrative curriculum. Journal of Curriculum Studies, 23(6), 107-117.

[7] Harrell, P. (2010). Teaching an integrated science curriculum: Linking teacher knowledge and teaching assignments. Issues in Teacher Education, 19(1), 145-165.

[8] Hinde, E., Osborn, S., \& Dorn, R. (2007). The integration of literacy and geography: The Arizona GeoLiteracy program's effect on reading comprehension. Theory and Research in Social Education, 35(3), 343-365.

[9] Kain, D.L. Cabbages and kings: Research directions in integrated/interdisciplinary curriculum. J. Educ. Thought 1993, 3, 312-331.

[10] Malik, A., \& Malik, R. (2011). Twelve tips for developing an integrated curriculum. Medical Teacher, 33(2), 99-104.

[11] Mustofa, J. (2011). Proposing a model for integration of social issues in school curriculum. International Journal of Academic Research, 3(1), 925-931.

[12] Park, M. (2008). The implementing curriculum integration: The experiences of Korean elementary teachers. Asia Pacific Education Revew, 9(3), 308-319.

[13] Vars, G. (2001). Can curriculum integration survive in an era of high-stakes testing? Middle School Journal, 33(2), 7-17.

[14] Shriner, M., Schlee, B., \& Libler, R. (2010). Teachers' perceptions, attitudes and beliefs regarding curriculum integration. The Australian Educational Researcher, 37(1), 5162.

[15] Watkins, D., \& Kritsonis, W. (2011). Developing and designing an effective school curriculum: Enhancing student achievement based on an integrated curriculum model and ways of knowing through the realm of meaning. Focus on College, Universities, and Schools, 6(1), 1-15. 